\title{
DINAMIKA RISIKO KREDIT BANK PEMBANGUNAN DAERAH DI INDONESIA PERIODE 2011-2016
}

\author{
Ishak Ramli, Elson Kristian
}

Program Studi Magister Akuntansi Fakultas Ekonomi

Universitas Tarumanagara, Jakarta

Email: ishakr@fe.untar.ac.id,elsonkristian@gmail.com

Masuk : 31-03-2018, revisi: 23-01-2019, diterima untuk diterbitkan : 30-09-2019

\begin{abstract}
ABSTRAK
Tujuan penelitian adalah untuk menganalisis pengaruh variabel spesifik perbankan seperti informasi modal terhadap aktiva tertimbang menurut risiko diukur dengan rasio $C A R$, informasi total pinjaman terhadap total aset diukur dengan rasio LTA, informasi ukuran bank, informasi laba setelah pajak terhadap rata-rata aset diukur dengan rasio $R O E$, dan informasi inefisiensi bank yang diukur dengan rasio BOPO terhadap Risiko Kredit yang diukur dengan rasio NPL. Populasi yang dijadikan obyek penelitian berjumlah 26 BPD di Indonesia 2011-2016. Penelitian ini menggunakan data panel dengan jumlah data observasi sebanyak 156. Data sekunder diolah dengan metode Generalized Method of Moment. Hasil penelitian menunjukkan bahwa informasi modal terhadap aktiva tertimbang menurut risiko, laba setelah pajak terhadap rata-rata modal, dan inefisiensi berpengaruh negatif terhadap Risiko Kredit pada BPD di Indonesia. Sementara informasi total pinjaman terhadap total aset dan ukuran bank berpengaruh positif terhadap risiko kredit pada BPD di Indonesia.
\end{abstract}

Kata kunci: $N P L, L T A, C A R$, Ukuran Bank, ROE, BOPO.

\section{ABSTRACT}

The purpose of this study is to analyze the effect of specific bank variables represented by CAR (Capital Adequacy Ratio), LTA (Loan to Asset) Ratio, Size, ROE (Return on Equity) Ratio, and Inefficiency on credit risk measured by NPL on Regional Development Bank in Indonesia. Population of this research taken as the object of observation amounted to 26 Regional Development Banks in Indonesia in the period 2011 - 2016. This research is using panel data with total data amounted to 156 firm-years observation. Secondary data is processed with Generalized Method of Moment. The result showed CAR, ROE, and Inefficiency have negative impact on NPL in Regional Development Bank in Indonesia. Meanwhile, LTA and Size have positive impact on NPL in Regional Development Bank in Indonesia.

Keywords: NPL, LTA, CAR, SIZE, ROE, Inefficiency.

\section{PENDAHULUAN}

\section{Latar Belakang}

Risiko kredit macet yang tidak ditangani dengan baik nantinya dapat mengakibatkan bank mengalami kerugian bahkan kebangkrutan yang dapat mengancam kondisi keuangan bank dan negara. Manajemen kredit memiliki berperan penting untuk memastikan keamanan sistem keuangan dan bertindak sebagai sistem peringatan dini kepada otoritas regulator sistem perbankan. Bank milik pemerintah memiliki risiko kredit macet yang lebih rendah meskipun bank milik pemerintah memiliki risiko operasional yang lebih tinggi dibandingkan bank milik swasta. Hal ini menunjukkan bahwa adanya perlindungan dari pemerintah membuat bank lebih berani mengambil risiko.

Literatur yang ada menunjukkan risiko kredit dipengaruhi oleh variabel spesifik bank dan variabel makroekonomik. Namun, pengaruh variabel spesifik bank seperti informasi total pinjaman terhadap total aset, informasi ukuran bank, informasi modal terhadap aktiva tertimbang menurut risiko, informasi laba setelah pajak terhadap rata-rata modal, dan informasi inefisiensi Bank terhadap risiko kredit yang diukur dengan menggunakan $N P L$ 
Penelitian-penelitian terdahulu yang dilakukan pada beberapa negara menghasilkan kesimpulan yang berbeda-beda mengenai pengaruh informasi-informasi tersebut terhadap risiko kredit. Informasi total pinjaman terhadap total aset yang diukur Rasio Pinjaman terhadap Aset (LTA) memiliki pengaruh positif signifikan dan pengaruh yang tidak signifikan terhadap risiko kredit yang diukur menggunakan NPL. Kecenderungan bank yang lebih mengutamakan keuntungan yang mungkin diperoleh dari pinjaman berisiko tinggi daripada biaya pinjamannya tercermin dari rasio ini. Ukuran bank dapat mempengaruhi risiko kredit secara positif ataupun secara negatif. adanya anggapan terlalu besar untuk gagal sehingga bank-bank besar cenderung berani dalam memberikan pinjaman yang berisiko sehingga risiko kredit meningkat namun bank besar memiliki sumber daya yang lebih baik sehingga memungkinkan mereka untuk mengevaluasi pemberian pinjaman dan memastikan bahwa pinjaman yang diberikan berkualitas baik. Informasi modal bank terhadap aktiva tertimbang menurut risiko yang diukur dengan rasio kecukupan modal $(C A R)$ memiliki pengaruh positif maupun negatif terhadap risiko kredit. Hal ini disebabkan oleh kecenderungan para manajer untuk mendapatkan keuntungan yang sebesarbesarnya dari pemberian kredit.

Manajer bank yang memiliki modal besar cenderung memberikan pinjaman yang berisiko tinggi karena merasa kerugian yang mungkin terjadi akibat kredit macet dapat ditutupi dengan modal bank sementara manajer bank dengan modal kecil mengambil risiko kredit macet demi mendapatkan keuntungan yang lebih besar. Informasi laba setelah pajak terhadap rata-rata modal memiliki pengaruh positif dan negatif terhadap risiko kredit. Bank dengan laba kecil cenderung memberikan pinjaman yang lebih berisiko dalam rangka meningkatkan laba mereka yang artinya juga meningkatkan kinerja mereka. Sementara, bank dengan laba besar cenderung memperoleh laba mereka dari pemberian pinjaman yang berisiko. Demikian halnya dengan informasi inefisiensi bank yang diukur menggunakan rasio BOPO. Informasi ini dapat memiliki pengaruh yang positif dan negative terhadap risiko kredit. Alasan inefisiensi biaya membuat bank enggan untuk mengeluarkan biaya lebih untuk mengevaluasi kualitas pinjaman yang mereka berikan. Sebaliknya, ketika bank beroperasi dengan inefisiensi yang tinggi artinya bank tidak memiliki kemampuan untuk mengelola pinjaman yang mereka berikan dengan baik karena pengelolaan biaya internal juga buruk. Hasil penelitian terdahulu yang masih belum konsisten menarik perhatian penulis untuk melakukan penelitian lebih lanjut mengenai pengaruh informasiinformasi tersebut terhadap risiko kredit pada Bank Pembangunan Daerah di Indonesia.

\section{Kajian Teori}

Pinjaman merupakan salah sumber pendapatan bank yang kurang likuid tetapi memiliki tingkat pengembalian yang lebih tinggi dari sumber pendapatan bank lainnya (Ghosh, 2015; Malimi, 2017). Namun, karena pinjaman kurang likuid maka bank harus menghadapi risiko berupa risiko kredit. Risiko kredit memiliki hubungan yang erat dengan kualitas aset, kegagalan bank (Samad, 2012 dalam Makri, 2016), dan gangguan stabilitas finansial (Ninimaki, 2012 dalam Makri, 2016). Risiko kredit merupakan salah satu masalah penting yang harus dihadapi oleh institusi keuangan termasuk bank karena risiko kredit dapat mengancam sistem perbankan (Makri, 2016). Risiko kredit bukan hanya memiliki hubungan yang erat dengan kualitas aset tetapi juga bergantung pada kualitas aset yang dimiliki oleh bank dan tercermin dari tingkat risiko kredit yang diukur dengan menggunakan rasio NPL (Ekanayake, E.M. N.N. \& Azeez A.A., 2015) karena kredit merupakan aset milik bank. Untuk mengukur risiko kredit dengan menggunakan rasio NPL dibutuhkan informasi mengenai total kredit bermasalah dan total pinjaman. Ada beberapa variabel yang dapat mempengaruhi NPL di antaranya adalah: informasi total pinjaman terhadap total aset yang diukur rasio pinjaman terhadap aset (LTA) (Ekanayake, E.M. N.N. \& Azeez A.A., 2015; Malimi, 2017; Sheefeni, J.P.S, 2015), ukuran bank (Makri, 2016; Sheefeni, 
J.P.S, 2015), informasi modal terhadap aktiva tertimbang menurut risiko yang diukur menggunakan rasio CAR (Makri, Tsagkanos, Bellas, 2013), informasi laba setelah pajak terhadap rata-rata modal yang diukur dengan menggunkan rasio $R O E$ (Sheefeni, 2015; Makri, Tsagkanos, \& Bellas, 2014; Chaibi, 2016), dan informasi Inefisiensi yang diukur dengan rasio BOPO (Chaibi \& Ftiti, 2014).

Informasi total pinjaman terhadap aset yang diukur dengan rasio pinjaman terhadap aset (LTA) menunjukkan seberapa besar kemampuan bank untuk memberikan pinjaman terutama bila dibandingkan dengan informasi mengenai total aset (Ekanayake, E.M. N.N. \& Azeez A.A., 2015; Malimi, 2017; Sheefeni, J.P.S, 2015) selain itu. Infomasi total pinjaman terhadap total aset merupakan faktor penting dalam bisnis bank karena informasi total pinjaman terhadap total aset dapat menunjukkan seberapa besar ambisi bank dan seberapa besar keberanian bank dalam mengambil risiko untuk memperoleh pendapatan dari pemberian kredit (Malimi, 2017). Seperti instrumen hutang lain, pinjaman yang diberikan membuat bank mendistribusikan ulang asetnya terutama kas selama jangka waktu tertentu (Sheefeni, 2015). Dari pengertian di atas, semakin banyak pinjaman yang diberikan maka semakin banyak pula kemungkinan terjadinya risiko kredit pada bank terutama kredit macet. Hal ini terjadi karena aset yang seharusnya dapat digunakan oleh bank untuk tujuan produktif sebagian besar digunakan untuk memberikan pinjaman yang belum tentu dapat memberikan pendapatan bagi bank.

Semakin besar ukuran bank maka semakin besar pula kemungkinan bank mengalami kredit macet (Makri, 2016; Sheefeni, J.P.S, 2015). Adanya anggapan terlalu besar untuk gagal membuat bank-bank dengan total aset besar memiliki kemampuan untuk mengambil risiko lebih banyak dalam memberikan pinjaman bahkan kepada debitor berkualitas rendah (Boyd \& Getler, 1994; Boyd et al. 2009; Walter, 2009; Laeven et al. 2014 dalam Makri, 2016). Dari pengertian di atas, bank besar merasa bahwa aset mereka cukup untuk menutupi kerugian yang timbul akibat kredit macet sehingga bank-bank berukuran besar cenderung memilih untuk mengambil keuntungan jangka pendek dengan memberikan pinjaman berisiko tinggi dengan bunga yang tinggi pula.

Informasi modal terhadap aktiva tertimbang menurut risiko diperlukan untuk mengetahui seberapa besar kemampuan bank untuk menyerap potensi kerugian dan melindungi debitornya (Dang, 2011 dalam Malimi, 2017). Informasi modal terhadap aktiva tertimbang menurut risiko diukur dengan rasio kecukupan modal (CAR). Informasi ini mencerminkan bagaimana kemampuan bank dalam menghadapi risiko (Makri, 2016; Tsagkanos \& Bellas, 2013). Ada 2 organisasi yang mengatur tentang informasi modal terhadap aktiva tertimbang menurut risiko yang diukur dengan CAR dalam perbankan yaitu BIS (The Bank International Settlement) dan BI (Bank Indonesia). Menurut BIS berdasarkan kerangka kerja Basel III ada tiga ukuran dalam mengukur rasio kecukupan modal yaitu: Ekuitas biasa dibagi dengan Aktiva Tertimbang menurut risiko (RWA) tidak kurang dari 4.5\%, Modal Tier 1 dibagi dengan RWA tidak kurang dari 6\%, dan Total Modal dibagi dengan RWA tidak kurang dari 8\% (Malimi, 2017). Sementara untuk rasio kecukupan modal BI ada di angka 8\% (PBI No. 15/12/PBI/2013).

Dari pengertian di atas, dapat dikatakan bahwa bank dengan modal yang besar dapat terhindar dari risiko kredit karena apabila bank menderita kerugian dari kredit macet dan modal mereka tidak dapat menutupi kerugian tersebut maka bank dapat mengalami kebangkrutan. Sebaliknya, apabila bank memiliki modal yang cukup untuk menutupi kerugian akibat kredit macet maka bank dapat tetap beroperasi. Namun, besarnya modal yang dimiliki bank dapat menjadi alasan untuk memberikan kredit berisiko karena adanya anggapan modal mereka cukup untuk menutupi 
kerugian dari risiko kredit.

Informasi laba setelah pajak terhadap rata-rata modal dapat mencerminkan profitabilitas sebuah bank. Profitabilitas berkaitan erat dengan perilaku bank dalam menghadapi risiko. Bank dengan profitabilitas tinggi memiliki insentif yang lebih rendah untuk mengambil risiko yang besar (Makri, Tsagkanos, \& Bellas, 2014). Bank dengan profitabilitas tinggi juga dapat menahan diri untuk memperoleh keuntungan jangka pendek (Sheefeni, 2015). Bank dapat mencoba meyakinkan investor dengan profitabilitasnya dengan menaikkan pendapatannya dengan mengorbankan risiko kredit macet di masa depan (Louzis, Vouldis, \& Metaxas, 2012). Informasi laba setelah pajak terhadap rata-rata modal diukur dengan menggunakan rasio ROE. Dari definisi di atas, dapat disimpulkan bahwa semakin besar profitabilitas bank maka pengambilan risiko kreditnya semakin kecil. Sebaliknya, semakin kecil profitabilitas bank maka semakin besar risiko kredit yang dialami oleh bank. Hal ini terjadi karena bank memiliki kualitas manajemen yang rendah sehingga memiliki kecenderungan fokus pada tujuan jangka pendek yaitu memperoleh keuntungan yang sebesar-besarnya. Sehingga, seringkali bank memberikan pinjaman berisiko tinggi tanpa mengevaluasi terlebih dahulu mengenai kemungkinan pinjaman tersebut menjadi bermasalah di masa yang akan datang.

Informasi inefisiensi ini diukur dengan menggunakan informasi biaya operasional terhadap pendapatan operasional (Louzis, Vouldis, \& Metaxas, 2011, Chaibi \& Ftiti, 2014, Vatansever \& Hepsen, 2013) atau lebih dikenal dengan rasio BOPO. Upaya bank untuk meningkatkan efisiensi biaya dan pengendalian risiko mereka patut diharapkan dapat mempengaruhi evolusi risiko kredit yang diukur dengan rasio NPL (Louzis, Vouldis, \& Metaxas, 2011). Dari pengertian di atas, dapat disimpulkan bahwa inefisiensi dan pengendalian kredit bukanlah hal yang berjalan beriringan. Bank dengan inefisiensi rendah tentunya akan berusaha agar risiko kredit mereka juga rendah. Namun, upaya bank untuk menekan inefisiensi dapat berbalik arah karena apabila mereka melakukan efisiensi pada pos biaya yang digunakan untuk mengevaluasi pinjaman maka risiko kredit dapat meningkat. Inefisiensi dapat mempengaruhi risiko kredit karena apabila sebuah bank tidak efisien maka risiko kredit mereka dapat meningkat akibat kemampuan manajemen yang tidak dapat mengendalikan biaya. Sebaliknya, apabila manajemen tidak mengalokasikan biaya untuk mengevaluasi kredit bank akan terlihat efisien dalam jangka pendek tetapi untuk jangka panjang risiko kredit bank dapat meningkat.

Kerangka pemikiran dalam penelitian ini seperti digambarkan berikut ini:

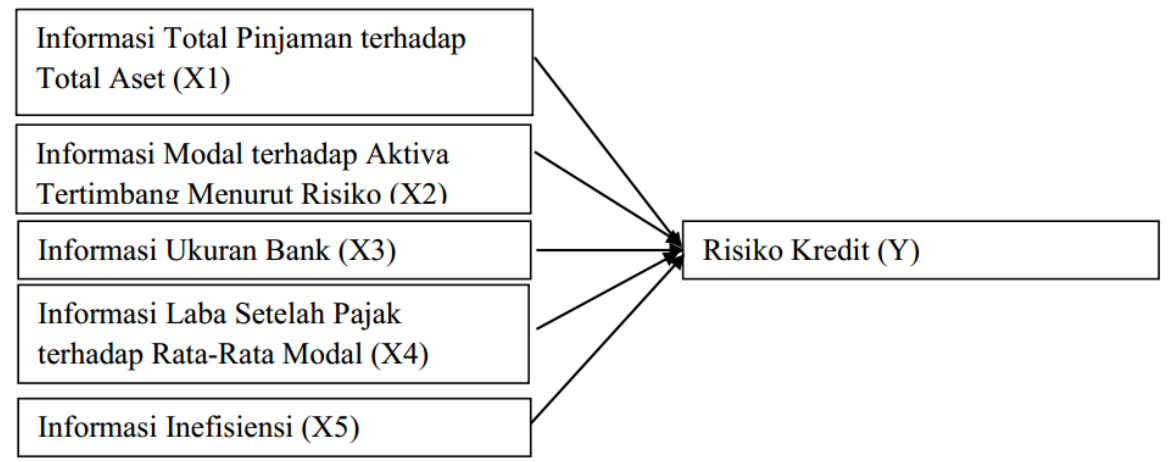

Gambar 1.

Kerangka Pemikiran

Sumber: Data Olahan Penulis (2017) 
Berdasarkan literatur penelitian yang telah dipaparkan sebelumnya, maka hipotesis penelitian ini adalah sebagai berikut:

$\mathrm{H}_{1}$ : Informasi Total Pinjaman terhadap Total Aset berpengaruh positif terhadap Risiko Kredit.

$\mathrm{H}_{2}$ : Informasi Modal terhadap Aktiva Tertimbang Menurut Risiko berpengaruh positif terhadap Risiko Kredit.

$\mathrm{H}_{3}$ : Informasi Ukuran Bank berpengaruh positif terhadap Risiko Kredit.

$\mathrm{H}_{4}$ : Informasi Laba Setelah Pajak terhadap Rata-Rata modal berpengaruh positif terhadap Risiko Kredit.

$\mathrm{H}_{5}$ : Informasi Inefisiensi berpengaruh positif terhadap Risiko Kredit.

\section{METODE PENELITIAN}

\section{Metodologi}

Penelitian ini merupakan penelitian kuantitatif. Yang menjadi fokus dalam penelitian ini adalah faktor-faktor yang mempengaruhi pergerakan risiko kredit pada Bank Pembangunan Daerah (BPD) di Indonesia. Pergerakan risiko kredit yang fluktuatif bahkan pada beberapa bank melewati batas risiko kredit yang telah ditetapkan BI merupakan alasan pemilihan variabel pada penelitian ini. Penelitian ini bersifat penelitian deskriptif. Populasi yang digunakan dalam ini adalah seluruh Bank Pembangunan Daerah di Indonesia yaitu 26 bank. Penelitian ini menggunakan data panel dari laporan tahunan dan laporan keuangan 26 Bank Pembangunan Daerah di Indonesia periode 2011-2016. Teknik penarikan sampel yang digunakan adalah total sampling karena jumlah populasi yang digunakan kurang dari 100 dan keseluruhan populasi digunakan sebagai sample.

Variabel operasional dalam penelitian ini terdiri dari variabel dependen dan variabel independen. Yang bertindak sebagai variabel dependen adalah Risiko Kredit yang diukur dengan menggunakan rasio NPL. Sementara, variabel independen terdiri dari informasi informasi total pinjaman terhadap total aset yang diukur menggunakan rasio LTA (X1), informasi modal terhadap aktiva tertimbang menurut risiko yang diukur dengan $C A R(\mathrm{X} 2)$, ukuran perusahaan yang diukur dengan total aset (X3), informasi laba setelah pajak terhadap rata-rata modal yang diukur dengan rasio $R O E(\mathrm{X} 4)$, dan informasi inefisiensi yang diukur dengan rasio BOPO (X5).

Untuk mengukur informasi total pinjaman terhadap total aset digunakan rasio LTA, dengan rumus:

$$
\text { LTA }=\frac{\sum \text { Total Pinjaman }}{\sum \text { Total Aset }}
$$

Untuk mengukur informasi modal terhadap aktiva tertimbang menurut risiko digunakan $C A R$, dengan rumus:

$$
\text { CAR }=\frac{\sum \text { Modal Bank }}{\sum \text { Aktiva Tertimbang Menurut Risiko }}
$$

Untuk mengukur informasi ukuran bank digunakan log natural dari total aset, dengan rumus:

$$
\text { SIZE }=\quad \ln (\text { Total Aset })
$$


Untuk mengukur informasi laba setelah pajak terhadap rata-rata modal digunakan rasio $R O E$, dengan rumus:

$R O E=\frac{\sum \text { Laba Setelah Pajak }}{\text { Rata-rata modal }}$

Untuk mengukur informasi inefisiensi biaya digunakan rasio BOPO, dengan rumus:

$$
\text { BOPO }=\frac{\sum \text { Biaya Operasional Bank }}{\sum \text { Pendapatan Operasional Bank }}
$$

Pengujian model penelitian ini menggunakan uji regresi dengan metode GMM (Generalized Method of Moment) dengan menggunakan software Eviews 8.0. Menurut Sarwono (2016), metode ini digunakan untuk mencegah korelasi antara variabel bebas dengan error. Pengukuran dilakukan menggunakan time lag t-1 sesuai dengan penelitian Abid, Lobna, Ouertani, E. M., \& Zhouari-Ghorbel, Sonia, 2014, Makri, 2016, Makri, Tsagkanos, \& Bellas, 2013, dan Duong \& Huong, 2017. Time lag ini digunakan untuk menunjukkan pengaruh variabel independen pada risiko kredit tahun berikutnya (Louzis, 2012; Duong \& Huong, 2017).

Penelitian ini menggunakan analisis regresi dengan metode generalized method of moments dengan tingkat keyakinan $95 \%$.

Model Penelitian adalah sebagai berikut:

$\mathrm{Y} 1=\mathrm{a}+\mathrm{b} 1 \mathrm{X} 1+\mathrm{b} 2 \mathrm{X} 2+\mathrm{b} 3 \mathrm{X} 3+\mathrm{b} 4 \mathrm{X} 4+\mathrm{b} 5 \mathrm{X} 5+\mathrm{e}$

Keterangan:

Y1: Risiko kredit diukur dengan Non-Performing Loan (NPL)

a: Konstanta

b: Koefisien Regresi

$\mathrm{X}_{1}$ : Informasi modal terhadap aktiva tertimbang menurut risiko diukur dengan Capital Adequacy Ratio (CAR)

$\mathrm{X}_{2}$ : Informasi total pinjaman terhadap total aset diukur dengan Loan to Asset Ratio (LTA)

$\mathrm{X}_{3}$ : Informasi Ukuran Bank (SIZE)

$\mathrm{X}_{4}$ : Informasi laba setelah pajak terhadap rata-rata modal diukur dengan Return On Equity $(R O E)$

$\mathrm{X}_{5}$ : Informasi inefisiensi diukur dengan rasio BOPO

\section{HASIL DAN PEMBAHASAN}

\section{Hasil Uji}

Analisis regresi dengan model $G M M$ digunakan penulis untuk memperoleh nilai $\mathrm{R}^{2}$, Adjusted $\mathrm{R}^{2}$ dan $J$ Statistics sebagai indikator kebenaran model. Selain itu, untuk hasil penelitian dapat dilihat dari koefisien yang dihasilkan.

Tabel 4.2 Hasil Pengujian GMM

Sumber: Olahan Penulis dengan menggunakan Eviews 8 (2017)

\begin{tabular}{|c|c|c|}
\hline Variable & Coefficient & Prob. \\
\hline CAR & -0.088561 & 0.0114 \\
\hline LTA & 0.004842 & 0.8443 \\
\hline SIZE & 0.008591 & 0.0019 \\
\hline ROE & -0.131311 & 0.0044 \\
\hline BOPO & -0.006419 & 0.8711 \\
\hline
\end{tabular}




\begin{tabular}{|c|c|c|}
\hline Variable & Coefficient & Prob. \\
\hline R-squared & 0.309661 & \\
\cline { 1 - 2 } J-statistic & 0.000000 & \\
\cline { 1 - 2 }
\end{tabular}

Nilai R2 sebesar 0,309661. Nilai ini memiliki arti variabel dependen dalam penelitian ini risiko kredit dapat dijelaskan menggunakan variabel independennya yaitu informasi modal terhadap aktiva tertimbang menurut risiko, informasi total pinjaman terhadap total aset, informasi ukuran bank, informasi laba setelah pajak terhadap rata-rata modal, dan informasi inefisiensi sebesar 0,309661 atau 30,9661\% sementara sisanya sebesar 0,690339 atau 69,0339\% variabel dependen (risiko kredit) dijelaskan oleh variabel lain di luar penelitian ini. Nilai J Statistics sebesar 0,000000. Nilai ini merupakan kecocokan model dalam GMM. Nilai ini menganut distribusi Chi Square yang mencerminkan seberapa benar proporsi yang diharapkan dalam model teori sesuai dengan kenyataan yang ada (Sarwono, 2016). Nilai J statistic ini merupakan nilai hitung oleh karena itu harus dibandingkan dengan nilai tabel Chi Square. Setelah dibandingkan dengan nilai tabel hasil yang didapat adalah 0,711 yang artinya lebih besar dari nilai hitung. Berdasarkan asumsi yang ada maka dapat dinyatakan bahwa model GMM yang dibuat telah valid.

Hasil uji menunjukkan bahwa informasi total pinjaman terhadap total aset yang diukur dengan rasio LTA memiliki nilai koefisien 0,004842 yang berarti informasi ini berpengaruh positif terhadap risiko kredit sehingga $\mathrm{H}_{1}$ diterima.

Hasil uji menunjukkan bahwa informasi modal terhadap aktiva tertimbang menurut risiko yang diukur dengan $C A R$ memiliki nilai koefisien -0,088561 yang berarti informasi ini berpengaruh negatif tehadap risiko kredit sehingga $\mathrm{H}_{2}$ ditolak.

Hasil uji menunjukkan bahwa informasi ukuran bank yang diukur dengan SIZE memiliki nilai koefisien 0,008591 yang berarti informasi ini berpengaruh positif terhadap risiko kredit sehingga $\mathrm{H}_{3}$ diterima

Hasil uji menunjukkan bahwa informasi laba setelah pajak terhadap rata-rata modal yang diukur dengan rasio $R O E$ memiliki nilai koefisien -0,131311 yang berarti informasi ini berpengaruh negative terhadap risiko kredit sehingga $\mathrm{H}_{4}$ ditolak.

Hasil uji menunjukkan bahwa informasi inefisiensi yang diukur dengan rasio BOPO memiliki nilai koefisien $-0,006419$ yang berarti informasi ini berpengaruh negatif terhadap risiko kredit sehingga $\mathrm{H}_{5}$ ditolak.

\section{KESIMPULAN DAN SARAN \\ Diskusi}

Berdasarkan hasil pengujian dengan menggunakan Eviews 8.0 dapat disimpulkan bahwa informasi total pinjaman terhadap total aset yang diukur dengan rasio LTA, dan informasi ukuran bank, berpengaruh positif terhadap risiko kredit pada Bank Pembangunan Daerah di Indonesia periode 2011-2016 sedangkan informasi mengenai modal terhadap aktiva tertimbang menurut risiko yang diukur menggunakan $C A R$, informasi laba setelah pajak terhadap rata-rata modal yang diukur dengan rasio $R O E$, dan informasi inefisiensi yang diukur dengan rasio BOPO berpengaruh negatif terhadap risiko kredit pada Bank Pembangunan Daerah di Indonesia periode 2011-2016.

Hal ini disebabkan karena BPD di Indonesia memberikan banyak pinjaman demi pembangunan daerah sehingga aset BPD banyak terpakai untuk memberikan pinjaman termasuk pinjaman 
dengan kualitas rendah. Namun, pengaruh ini tidak signifikan karena sebagian besar BPD yang memiliki pertumbuhan kredit tinggi tidak memiliki risiko kredit yang tinggi juga terlihat dari 22 BPD yang bebas dari masalah kredit macet meskipun aset mereka didominasi oleh pinjaman tetapi risiko kredit mereka berada di bawah 5\%. Pengaruh informasi modal terhadap aktiva tertimbang menurut risiko terhadap risiko kredit pada BPD di Indonesia berpengaruh negatif dan signifikan. BPD dengan rasio modal baik besar maupun kecil memiliki kemampuan dalam menahan diri mereka dengan tidak memberikan pinjaman berisiko meskipun dengan bunga yang tinggi dengan demikian anggapan mengenai moral hazard tidak berlaku pada BPD di Indonesia.

Kondisi ini membuat BPD di Indonesia seharusnya dapat meningkatkan kualitas mereka dengan memanfaatkan modal yang ada terlihat dari 22 BPD yang ada permodalan mereka terbilang cukup kuat karena berada di atas ketetapan permodalan yang ditetapkan oleh Bank Indonesia sebesar $8 \%$ dan memiliki risiko kredit di bawah 5\%. Informasi ukuran bank berpengaruh positif dan signifikan terhadap risiko kredit. Berpengaruh positif artinya BPD dengan jumlah aset besar memiliki kecenderungan mengalami risiko kredit macet terlihat dari Bank Papua yang terbilang memiliki ukuran yang cukup besar risiko kredit mereka melampaui ketetapan Bank Indonesia. BPD di Indonesia memiliki kecenderungan untuk mengejar keuntungan jangka pendek tanpa memperdulikan risiko kredit yang mungkin timbul di kemudian hari terutama pada BPD yang memiliki profitabilitas relatif kecil. Sementara untuk BPD yang memiliki profitabilitas besar diharapkan mampu mempertahankan kinerja baik mereka sehingga tidak tergiur mencari keuntungan jangka pendek tanpa memperhatikan risiko kredit yang mungkin timbul di masa yang akan datang. Bank Papua yang meskipun inefisiensinya berada di angka 80,22\% tetapi risiko kreditnya mencapai $15,03 \%$ karena sejak 2010 terjadi kebijakan pemberian kredit dari kredit konsumtif menjadi kredit produktif. Bank Papua belum memiliki infrastruktur dan tenaga analis kredit yang memadai sehingga risiko kredit mereka meningkat melampaui batas yang ditentukan oleh Bank Indonesia. Sebenarnya, Bank Papua dapat mengatasi hal ini dengan mengeluarkan lebih banyak biaya untuk merekrut tenaga analis kredit yang kompeten serta meningkatkan infrastruktur dalam pemberian kredit produktif yang mereka miliki.

\section{Penutup}

Berdasarkan hasil pengujian dengan menggunakan Eviews 8.0 dapat disimpulkan bahwa informasi total pinjaman terhadap total aset yang diukur dengan rasio LTA, dan informasi ukuran bank, berpengaruh positif terhadap risiko kredit pada Bank Pembangunan Daerah di Indonesia periode 2011-2016 sedangkan informasi mengenai modal terhadap aktiva tertimbang menurut risiko yang diukur menggunakan $C A R$, informasi laba setelah pajak terhadap rata-rata modal yang diukur dengan rasio $R O E$, dan informasi inefisiensi yang diukur dengan rasio BOPO berpengaruh negatif terhadap risiko kredit pada Bank Pembangunan Daerah di Indonesia periode 2011-2016. Keterbatasan dalam penelitian ini adalah sampel yang digunakan hanya Bank Pembangunan daerah dalam periode 2011-2016

Variabel independen yang digunakan dalam penelitian ini adalah informasi total pinjaman terhadap total aset yang diukur dengan rasio LTA, informasi modal terhadap aktiva tertimbang menurut risiko yang diukur dengan rasio CAR, Informasi ukuran perbankan yang diukur dengan logaritma natural total aset, informasi laba setelah pajak terhadap rata-rata modal yang diukur dengan menggunakan rasio ROE, dan informasi inefisiensi yang diukur dengan rasio BOPO. Variabel-variabel ini dapat menjelaskan variabel dependen berupa risiko kredit yang diukur dengan rasio NPL sebesar 30,97\%. Sementara, sebesar 69,03\% variabel dependen dijelaskan oleh variabel lainnya. 
Berdasarkan kesimpulan dan keterbatasan penelitian ini, terdapat beberapa saran yang diajukan untuk penelitian selanjutnya. Saran untuk akademisi yaitu menambah periode pengamatan sehingga hasil penelitian menjadi lebih baik, dan menambahkan variabel-variabel lain yang tidak diteliti dalam penelitian ini. Variabel-variabel tersebut dapat berupa variabel spesifik bank yang tidak diteliti dalam penelitian ini, variabel makroekonomik, maupun variabel non keuangan lainnya.

\section{REFERENSI}

Abid, Lobna, Ouertani, E. M., \& Zhouari-Ghorbel, Sonia (2014). Macroeconomic and BankSpecific Determinants of Household's Non-Performing Loans in Tunisia: a Dynamic Panel Data. Procedia Economics and Finance. 13

Al Khazali, O.M, \& Mirzaei, Ali. (2017). The Impact of Oil Price Movement on Bank NonPerforming Loans: Global Evidence from Oil Exporting Countries. Emerging Markets Review, $31:$ 193-208

AZ Al-Abedallat, \& FN Al-Shubri (2013). Analysis The Determinants of Credit Risk in Jordanian Banking: An Empirical Study. Management Research and Practice Vol. 5 Issue 3 (2013) pp: 21-30.

Brahmana, Rayenda, Puah, H. C., \& Chai, Michael (2016). Natural Disaster and Local Bank Non-Performing Loan: Case of Nias Tsunami 2004. Economics Bulletin, 36 : 2413-2421.

Chaibi, Hasna (2016). Determinants of Problem Loans: Non-performing Loans vs. Loan Quality Deterioration. International Business Research; Vol. 9, No. 10.

Chaibi, Hasna, \& Ftiti Zied (2014). Credit risk determinants: Evidence from a cross-country study. Research in International Business and Finance 33 (2015) 1-16

Duong, Nguyen Thuy, \& Huong, Tran Thi Thu (2016). The Analysis of Major Credit Risk Factors - The Case of the Vietnamese Commercial Banks. International Journal of Financial Research Vol. 8, No. 1; 2017

E, Gila-Gourgoura, E,Nikolaidou (2017). Credit Risk Determinants in the Vulnerable Economies of Europe: Evidence from the Spanish Banking System. International Journal of Business and Economic Sciences Applied Research Vol 10, Issue 1.

EMNN, Ekanayake, \& AA, Azeez (2015). Determinants of Non-Performing Loans in Licensed Commercial Banks: Evidence from Sri Lanka. Asian Economic and Financial Review. 5.

Ghosh, Amit. (2015). Banking-Industry Specific and Regional Economic Determinants of NonPerforming Loans: Evidence from US States. Journal of Financial Stability. 20 (93-104).

Gujarati, D.N. \& Porter, D.C. (2009). Basic Econometrics. (5thed). New York: MacGraw Hill.

Ianotta, Giuliano, Nocera, Giacomo, \& Sironi, Andrea (2013). The Impact of Government Ownership on Bank Risk. Journal of Financial Intermediation.

Louzis, Dimitrios P, Vouldis, Angelos T, Metaxas, Vasilios (2012). Macroeconomic and bankspecific determinants of non-performing loans in Greece: A comparative study of mortgage, business and consumer loan portfolios. Journal of Banking \& Finance 36 (2012) $1012-1027$

Makri, Vasili (2016). Towards an Investigation of Credit Risk Determinants in Eurozone Countries. Journal of Accounting and Management Information Systems. 15 : 27-57.

Makri, Vasili, Tsagkanos, Athanasios, \& Bellas, Athanasios (2014). Determinants of NonPerforming Loans: The Case of Eurozone. Paneconomicus. 61 : 193-206.

Malimi, Kilugala (2017). The Influence of Capital Adequacy, Profitability, and Loan Growth on Non-Performing Loans a Case of Tanzanian Banking Sector. International Journal of Economics, Business and Management Studies.

Mensah, F.A., \& Adjei, B.A (2015). Determinants of Non-Performing Loans in Ghana Banking 
Industry. International Journal of Computational Economics and Econometrics. Independence: Delmar Cengage Learning.

Rahman, Ataur MD, Asaduzzaman, \& MD, Hossin, S.MD (2017). Impact of Financial Ratios on Non-Performing Loans of Publicly Traded Commercial Banks in Bangladesh. International Journal of Financial Research. 8 (1).

Rehman, Ramiz Ur, Zhang, Junrui (2016). Political system of a country and its non-performing loans: a case of emerging markets. Int. J. Business Performance Management, Vol. 17, No. 3, 2016

Sarwono, Jonathan (2016). Prosedur- Prosedur Analisis Populer Aplikasi Riset Skripsi dan Tesis dengan Eviews. Jogjakarta: Gava Media.

Sheefeni, Sheefeni, P.J. (2015). Evaluating the Impact of Bank Specific Determinants of Non performing Loans in Namibia. Journal of Emerging Issues in Economics, Finance and Banking.

Sugiyono. (2007). Metode Penelitian Administasi. Bandung: Alvabeta.

Vatansever, Metin, \& Hepsen, Ali (2013). Determining Impacts on Non-Performing Loan Ratio in Turkey. Journal of Finance and Investment Analysis. 2 (4).

Website:

www.bi.go.id

www.bisnis.com

www.ojk.go.id

www.reuters.com

www.skalanews.com 